\title{
PENGARUH OPINI AUDIT DAN PERTUMBUHAN PERUSAHAAN TERHADAP PERGANTIAN KANTOR AKUNTAN PUBLIK
}

\author{
Sophia Andini \\ sophia.andini@kalbis.ac.id \\ Program Studi Akuntansi
}

Fakultas Bisnis Institut Teknologi dan Bisnis Kalbis

\begin{abstract}
This study aims to determine the factors affecting audit switching on manufacturing companies listed at Indonesia Stock Exchange (IDX). These factors include the audit opinion and companies' growth. This study used a population of companies listed on the Indonesia Stock Exchange (IDX). In addition, this study analyzed the impact of independent variables of the firm turnover using logistic regression analysis. Sampling was carried out in this study using purposive sampling method, which is a sampling method based on the characteristics or certain characteristics that are considered to have anything to jointed closely with the known properties of the population. Testing of the 188 companies listed on Indonesia Stock Exchange period 2013-2017 states that the audit opinion and company's growth have no significant effect on audit switching.
\end{abstract}

Keywords: auditor switch, audit opinion, companies' growth, and manufacturing companies

\begin{abstract}
ABSTRAK
Penelitian ini bertujuan untuk mengetahui faktor-faktor yang mempengaruhi pergantian Kantor Akuntan Publik (KAP) pada perusahaan manufaktur yang terdaftar pada Bursa Efek Indonesia (BEI). Faktor tersebut meliputi opini audit dan pertumbuhan perusahaan. Penelitian ini menggunakan populasi perusahaan manufaktur yang terdaftar di Bursa Efek Indonesia (BEI). Selain itu, penelitian ini menganalisis dampak variabel - variable independen terhadap pergantian Kantor Akuntan Publik (KAP) sebagai variabel dependen dengan menggunakan analisis regresi logistik. Pengambilan sampel dalam penelitian ini dilakukan dengan menggunakan metode purposive sampling yang merupakan metode pengambilan sampel berdasarkan ciri-ciri atau karakteristik tertentu yang dipandang mempunyai sangkut-paut yang erat dengan sifat populasi yang sudah diketahui. Penilitian dari 188 perusahaan yang terdaftar di Bursa Efek Indonesia periode 2013-2017 menjelaskan bahwa opini audit, dan pertumbuhan perusahaan tidak berpengaruh significant terhadap pergantian Kantor Akuntan Publik.
\end{abstract}

Kata kunci: pergantian Kantor Akuntan Publik, opini audit, pertumbuhan perusahaan dan perusahaan manufaktur

\section{PENDAHULUAN \\ Latar Belakang}

Permasalahan yang terjadi pada Enron dan Worldcom menimbulkan banyak sekali pertanyaan mengenai auditor karena melibatkan salah satu Kantor Akuntan Publik (KAP) Internasional yaitu Arthur Andersen (AA). Pihak yang paling bertanggung jawab dalam masalah ini ditujukan kepada auditor, karena independensi auditor merupakan salah satu faktor yang diduga memicu masalah tersebut (Giri, 2010)

Independesi auditor yang sering dipertanyakan menjadi masalah besar semenjak masalah Enron mencuat ke permukaan. Kritikan yang diterima menyebutkan bahwa asimetri kekuatan auditor dan manajer mungkin dapat melemahkan kemampuan auditor untuk memeriksa secara bebas berdasarkan pertimbangan profesionalnya (Chow, C. W., \& Rice, S. J., 1982). Hal tersebut terjadi 
bila ada ketidak cocokan dengan tujuan manajemen dengan auditor yang dapat menimbulkan opini audit yang tidak diinginkan oleh manajemen.

Tidak hanya opini audit yang diharapakan mampu memberikan gambaran jelas tentang kondisi perusahaan, saat bisnis sedang tumbuh pun, dibutuhkan audit dengan kualitas dan indepensi yang tinggi untuk mengurangi biaya agency (Nasser, A.A. T., Wahid, E. A., Syed Mustapha Nazri, S. N., \& Hudaib, M., 2006). Menurut Prastiwi \& Wilsya (2009) pertumbuhan perusahaan yang ditandai dengan perubahan total asset memiliki pengaruh yang signifikan terhadap pergantian KAP karena perusahaan dianggap mempunyai dana yang cukup untuk membayar fee audit kepada KAP big 4 yang lebih kredibel.

\section{Permasalahan}

1. Apakah opini audit berpengaruh terhadap pergantian KAP pada perusahaan manufaktur yang terdaftar pada Bursa Efek Indonesia?

2. Apakah pertumbuhan perusahaan berpengaruh terhadap pergantian KAP pada perusahaan manufaktur yang terdaftar pada Bursa Efek Indonesia?

\section{Tujuan}

1. Memberikan bukti empiris mengenai pengaruh opini audit terhadap pergantian KAP pada perusahaan manufaktur yang terdaftar pada Bursa Efek Indonesia

2. Memberikan bukti empiris mengenai pengaruh pertumbuhan perusahaan terhadap pergantian KAP pada perusahaan manufaktur yang terdaftar pada Bursa Efek Indonesia

\section{TINJAUAN PUSTAKA DAN PENGEMBANGAN HIPOTESIS \\ Landasan Teori}

Landasan teori merupakan bagian yang penting dalam sebuah penelitian. Manfaat landasan teori adalah agar penelitian dapat tepat sasaran dan efektif. Landasan teori dalam penelitian ini adalah: teori agensi,
Auditing, KAP, pergantian KAP, opini audit dan pertumbuhan perusahaan.

\section{a. Teori Keagenan (Agency Theory)}

Teori yang mendasari praktik kebanyakan bisnis perusahaan selama ini yaitu keagenan (agency theory). Dalam suatu perusahaan, pemegang saham merupakan principle dan manajer adalah agent mereka dimana principle mendelegasikan pembuatan keputusan mengenai perusahaan kepada manajer atau agent. Bagaimanapun juga, manajer tidak selalu bertindak sesuai keinginan pemegang saham. Tujuan utama teori keagenan (agency theory) adalah untuk menjelaskan bagaimana pihak-pihak yang melakukan hubungan kontrak dapat mendesain kontrak yang tujuannya untuk meminimalisasi biaya sebagai dampak adanya informasi yang tidak simetris dan kondisi ketidakpastian (Atkinson, A., \& Feltham, G., 1982)

Pendapat Praptitorini \& Januarti (2007) mengemukakan bahwa dibutuhkan pihak ketiga yang independen sebagai mediator pada hubungan antara principal dan agent. Pihak ketiga ini berfungsi untuk memonitor perilaku manajer (agent) apakah sudah bertindak sesuai dengan keinginan principle. Auditor adalah pihak yang dianggap mampu menjembatani kepentingan pihak pemegang saham (principle) dengan pihak manajer (agent) dalam mengelola keuangan perusahaan.

Hipotesis yang kedua juga didasarkan pada teori agensi. Nasser et al. (2006) menyatakan bahwa saat perusahaan mengalami pertumbuhan, perusahaan memerlukan auditor yang independen dan berkualitas tinggi untuk mengurangi biaya agensi sehingga perusahaan cenderung akan mempertahankan auditornya untuk menekan biaya agensi.

\section{b. Auditing}

Pengertian auditing menurut Agoes \& Hoesada (2012) Jasa yang diberikan auditor dalam memeriksa dan mengevaluasi laporan keuangan yang disajikan 
perusahaan. Tujuan auditor adalah untuk memperoleh bukti audit yang cukup dan tepat terkait dengan kepatuhan terhadap ketentutan dalam peraturan perundangundangan yang pada umumnya berdampak langsung dalam menentukan jumlah dan pengungkapan material dalam laporan keuangan.

\section{c. Kantor Akuntan Publik}

Menurut Peraturan Menteri Keuangan No.17/PMK.01/2008 tentang Jasa Akuntan Publik "Akuntan Publik adalah akuntan yang telah memperoleh izin dari Menteri Keuangan untuk memberikan jasa sebagaimana diatur dalam Peraturan Menteri Keuangan Nomor: 17/PMK.01/2008 tentang Jasa Akuntan Publik."

\section{d. Pergantian Kantor Akuntan Publik}

Pergantian Kantor Akuntan Publik (KAP) merupakan perpindahan auditor yang dilakukan oleh perusahaan (klien). Tindakan ini merupakan suatu keputusan yang melewati pemikiran yang panjang untuk merealisasikannya karena tindakan tersebut dapat mempengaruhi kualitas laporan keuangan yang akan dihasilkan dan juga berpengaruh terhadap keuntungan yang akan di capai oleh perusahaan tersebut.

\section{e. Opini Audit}

Opini audit merupakan pernyataan yang dikeluarkan oleh auditor atas kewajaran laporan keuangan klien yang dilaksanakan sesuai dengan standar audit dan temuan auditor. Pemberian opini audit merupakan tahap akhir dari proses audit oleh auditor eksternal mengenai kewajaran laporan keuangan, wajar tidak sama dengan benar (Agoes, S., \& Hoesada, J. , 2012).

Berdasarkan Agoes \& Hoesada (2012) terdapat lima jenis opini yang dapat diberikan oleh auditor eksternal:

1. Pendapat wajar tanpa pengecualian (unqualified opinion)
2. Pendapat wajar tanpa pengecualian dengan tambahan bahasa penjelas (unqualified opinion with explanatory paragraph)

3. Pendapat wajar dengan pengecualian (qualiefied opinion)

4. Pendapat tidak wajar (adverse opinion)

5. Tidak memberikan pendapat (disclaimer opinion)

\section{f. Pertumbuhan Perusahaan}

Tingkat pertumbuhan perusahaan merupakan ukuran seberapa baik perusahaan mempertahankan posisi ekonominya, baik dalam industrinya maupundalam kegiatan ekonomi secara keseluruhan (Weston dan Copeland, 1992 dalam Sumarwoto, 2006). Dalam penelitian ini pertumbuhan perusahaan diproksikan dengan tingkat penjualan perusahaan.

Bisnis yang sedang tumbuh membutuhkan audit dengan kualitas dan independensi yang tinggi untuk mengurangi biaya agensi serta memberikan layanan non-audit yang dibutuhkan untuk meningkatkan perluasan perusahaan (Nasser, A.A. T., Wahid, E. A., Syed Mustapha Nazri, S. N., \& Hudaib, M., 2006). Dengan demikian, perusahaan yang sedang mengalami pertumbuhan cenderung mempertahankan auditornya untuk menjaga kualitas audit dan untuk menekan biaya agensi.

\section{Pengembangan Hipotesis}

\section{Opini audit dengan pergantian KAP}

Setelah mengaudit laporan keuangan suatu perusahaan, auditor akan memberikan opininya terhadap laporan keuangan tersebut. Opini yang diberikan oleh auditor dapat mempengaruhi pengambilan keputusan yang dilakukan oleh para pihak yang berkepentingan, misalnya investor. Investor akan merasa lebih yakin untuk menanamkan modalnya pada perusahaan yang memiliki opini audit wajar tanpa pengecualian pada laporan keuangan. 
Wajar jika perusahaan publik mengharapkan opini yang dapat memberikan keuntungan bagi perusahaan karena berhubungan erat dengan harapan pada perusahaan tersebut. Manajer dapat menekan auditor untuk memberikan clean opinion dengan mengancam untuk berpindah auditor jika auditor tidak memberikan opini yang sesuai keinginan manajer. Manajer berusaha mendapatkan clean opinion karena opini audit dianggap dapat mempengaruhi harga saham perusahaan dan kompensasi manajer (Chow, C. W., \& Rice, S. J., 1982). Kondisi ini muncul saat perusahaan klien atau akuntan publik tidak setuju dengan opini audit sebelumnya atau yang akan datang.

Permasalahan ini dapat memicu salah satu pihak untuk memisahkan diri. Secara umum, auditee tentunya menginginkan laporan keuangannya mendapat opini wajar tanpa pengecualian dari KAP yang disewanya. Karena pendapat wajar tanpa pengecualian (unqualified opinion) atas laporan keuangan akan berpengaruh besar terhadap kelangsungan hidup (going concern) perusahaan serta penyedia dana, terlebih bagi perusahaan yang go public. Di sisi lain, akuntan publik ingin berlaku profesional sesuai dengan prinsip akuntansi yang berlaku umum dan standar profesional akuntan publik, sehingga apabila ada kondisi yang tidak sesuai dengan standar dalam pengauditan dapat menimbulkan konflik. Berdasarkan uraian tersebut serta mengacu pada penelitian sebelumnya maka dapat dirumuskan hipotesis sebagai berikut:

H1: Opini audit berpengaruh positif terhadap pergantian KAP

\section{Pertumbuhan perusahaan dengan pergantian KAP.}

Pertumbuhan perusahaan yang mengalami peningkatan membutuhkan audit dengan kualitas dan indepensi yang tinggi dikarenakan perluasan kegiatan dalam perusahaan yang semakin meluas. Sehingga dengan adanya pertumbuhan perusahaan, pergantian KAP akan sering dilakukan karena perusahaan menganggap bahwa KAP yang sedang mengaudit tidak mampu memenuhi adanya peningkatan kegiatan perusahaan yang semakin kompleks.

Nasser et al (2006) mengungkapkan ketika bisnis sedang tumbuh, dibutuhkan audit dengan kualitas dan independensi yang tinggi untuk mengurangi biaya agensi. Tingkat pertumbuhan perusahaan digambarkan dari tingkat penjualan karena penjualan merupakan aktivitas utama perusahaan. Selain itu tingkat pertumbuhan perusahaan merupakan ukuran seberapa baik perusahaan mempertahankan posisi ekonominya, baik dalam industrinya maupun dalam kegiatan ekonomi secara keseluruhan (Weston dan Copeland, 1992 dalam Sumarwoto, 2006). Berdasarkan uraian tersebut maka dapat dirumuskan hipotesis sebagai berikut

$\mathrm{H}$ 2: Pertumbuhan perusahaan berpengaruh positif terhadap pergantian KAP.

\section{METODE PENELITIAN}

\section{a. Rancangan penelitian}

Objek penelitian yang digunakan oleh peneliti yaitu opini audit, pertumbuhan perusahaan dan pergantian Kantor Akuntan Publik (KAP). Jenis penelitian yang digunakan adalah penelitian deskriptif dan penelitian asosiatif. Penelitian deskriptif dilakukan untuk mengetahui dan menjelaskan karakteristik variabel yang diteliti dalam suatu situasi. Menurut Sekaran (2006) penelitian asosiatif dapat mengetahui hubungan antar variabel dan bagaimana tingkat ketergantungan antar variabel independen dengan variabel dependen.

Unit analisis yang dipakai adalah perusahaan manufaktur go public yang terdaftar di Bursa Efek Indonesia (BEI) selama periode 2013-2017, sedangkan data penelitian yang digunakan dalam penelitian ini adalah data pooling dimana data tersebut merupakan gabungan antara cross section dan time series.

\section{b. Populasi dan Sample}

Penelitian ini menggunakan populasi perusahaan manufaktur go public yang 
terdaftar di Bursa Efek Indonesia (BEI) selama periode 2013-2017. Pengambilan sampel dalam penelitian ini dilakukan dengan menggunakan metode purposive sampling.

\section{c. Operasionalisasi Variabel}

\section{Variabel Dependen}

Variabel dependen adalah variabel yang tinggi rendah datanya sebagai dampak dari perubahan data variabel lain (Baroroh, 2013). Variabel dependen dalam penelitian ini adalah pergantian Kantor Akuntan Publik yang dilakukan oleh perusahaan klien. Variabel tersebut diukur dengan menggunakan pengukuran dummy (Nasser, A.A. T., Wahid, E. A., Syed Mustapha Nazri, S. N., \& Hudaib, M., 2006) dimana,

$1=$ perusahaan melakukan pergantian kantor akuntan publiknya

0 = tidak melakukan pergantian kantor akuntan publiknya

Variabel dependen ini disimbol dengan SWITCH

\section{Variabel Independen}

Variabel independen adalah variable yang datanya merupakan input dari suatu sistem dan datanya diduga mempengaruhi variable terikat (dependen) secara sistematis (Baroroh, 2013). Variabel independen dalam penelitian ini adalah sebagai berikut:

\section{a) Opini audit}

Opini audit menggambarkan pernyataan atas suatu asersi yang dikeluarkan oleh auditor atas kewajaran laporan keuangan klien yang dilaksanakan sesuai dengan standar audit dan temuan auditor. Dalam penelitian ini, opini audit dikelompokkan menjadi 2 (dua) kelompok yaitu kelompok opini wajar tanpa pengecualian (unqualified opinion) dan kelompok opini selain wajar tanpa pengecualian (wajar tanpa pengecualian dengan paragraf penjelas, wajar dengan pengecualian, tidak wajar dan disclaimer). Variabel opini audit diukur dengan pengukuran dummy (Damayanti, S., \& Sudarma, M., 2008) dimana,

$1=$ perusahaan yang menerima opini selain wajar tanpa pengecualian

$0=$ perusahaan yang menerima opini wajar tanpa pengecualian

Variabel ini disimbolkan dengan OA

\section{b) Pertumbuhan perusahaan}

Pertumbuhan perusahaan mengungkapkan tentang ukuran seberapa baik perusahaan mempertahankan posisi ekonominya, baik dalam industrinya maupun dalam kegiatan ekonomi secara keseluruhan. Tingkat pertumbuhan perusahaan digambarkan dari tingkat penjualan karena penjualan merupakan aktivitas utama perusahaan (Nasser, A.A. T., Wahid, E. A., Syed Mustapha Nazri, S. N., \& Hudaib, M., 2006). Kondisi pertumbuhan perusahaan dalam penelitian ini di identifikasikan dengan rumus:

$$
\Delta S=\frac{\mathrm{S} 1-\mathrm{St}-1}{\mathrm{St}-1}
$$

Di mana,

$\Delta \mathrm{S}=$ perubahan penjualan bersih

$\mathrm{S} 1$ = nilai penjualan bersih saat tahun amatan

St-1 = nilai penjualan bersih 1(satu) tahun sebelum tahun amatan

Variabel ini disimbolkan dengan PP

\section{d. Metode Analisis Data}

\section{Tahapan Regresi Logistik}

a) Menilai kelayakan model regresi

Ukuran untuk menilai kelayakan model regresi yaitu melalui Hosmer and Lemeshow's Goodness of Fit Test. Hipotesis untuk menilai kelayakan model regresi yaitu

Ho: Tidak ada perbedaan antara model dengan data 
Ha: Ada perbedaan antara model dengan data

Menilai kelayakan dari model regresi ini dapat dilakukan dengan memperhatikan goodness of fit model yang diukur dengan Chi-Square pada kolom Hosmer and Lemeshow's (Ghozali, 2011). Jika nilai Hosmer and Lemeshow Goodness-of-fittest statistics sama dengan atau kurang dari 0.05, maka hipotesis nol ditolak yang berarti ada perbedaan signifikan antara model dengan nilai observasinya sehingga Goodness fit model tidak dapat memprediksi nilai observasinya. Jika nilai Hosmer and Lemeshow Goodnessof-fit-test statistics lebih besar dari 0.05, maka hipotesis nol tidak dapat ditolak dan berarti model mampu memprediksi nilai observasinya atau dapat dikatakan model dapat diterima karena cocok dengan data observasinya. Hal ini berarti model regresi layak dipakai untuk analisis selanjutnya, karena tidak ada perbedaan yang nyata antara klasifikasi yang diprediksi dengan klasifikasi yang diamati.

\section{b) Menilai keseluruhan model regresi (Overall Fit Model)}

Dalam menilai keseluruhan model dapat dilakukan dengan memperhatikan nilai -2LL (-2 log Likelihood). Hipotesis untuk menilai model fit yaitu

Ho: Model yang dihipotesiskan fit dengan data

Ha: Model yang dihipotesiskan tidak fit dengan data

Statistik -2LL dapat digunakan untuk menentukan jika variabel independen ditambah ke dalam model apakah secara signifikan memperbaiki model fit (Ghozali, 2011)

Apabila nilai -2LL pada kondisi awal (Blok 0) terjadi penurunan pada kondisi selanjutnya (Blok 1) menunjukkan bahwa model regresi yang lebih baik dibandingkan sebelum variabel independen dimasukkan dalam model.
Log Likelihood pada regresi logistik mirip dengan pengertian Sum of Square Error pada model regresi, sehingga penurunan Log Likelihood menunjukkan model regresi yang semakin baik. Adanya pengurangan nilai antara - $2 \log L$ awal (initial - 2LL function) dengan nilai - $2 \log L$ pada langkah berikutnya menunjukkan bahwa model yang dihipotesiskan fit dengan data (Ghozali, 2011).

\section{c) Koefisien determinasi (Cox and Snell's $R$ Square)}

Cox and Snell's $R$ Square merupakan ukuran yang mencoba meniru ukuran $R 2$ pada multiple regression yang didasarkan pada teknik estimasi likelihood. Nilai Nagelkerke's $R 2$ dapat diinterpretasikan seperti nilai R2 pada multiple regression. Berdasarkan nilai Nagelkerke's $R 2$ dapat diketahui seberapa jauh kemampuan model dalam menerangkan variasi variabel independen. Nilai ini menunjukkan variabilitas variabel dependen yang dapat dijelaskan oleh variabilitas variable independen, sedangkan sisanya dijelaskan oleh variable - variabel lain di luar model penelitian (Ghozali, 2011).

\section{d) Matriks klasifikasi}

Matriks klasifikasi menunjukkan kekuatan prediksi dari model regresi untuk memprediksi kemungkinan pergantian KAP yang dilakukan oleh perusahaan.Dalam output regresi logistik, angka ini dilihat pada Classification Table

\section{e) Uji multikolinearitas}

Model regresi yang baik adalah regresi dengan tidak adanya gejala korelasi yang kuat di antara variabel bebasnya. Pengujian multikolinearitas dalam regresi logistik menggunakan matriks korelasi antarvariabel bebas untuk melihat besarnya korelasi antarvariabel bebas. Apabila nilai koefisien korelasi antar variabel bebas lebih kecil dari 0,9 berarti tidak terdapat gejala multikolinearitas yang serius antar variabel bebas tersebut (Ghozali, 2011).

\section{Pengujian Hipotesis}


Pengujian hipotesis dalam penelitian ini menggunakan analisis multivariate dengan menggunakan regresi logistik (logistic regresion), yang variabel bebasnya merupakan kombinasi antara metrik dan non metric (nominal). Regresi logistik adalah regresi yang digunakan untuk menguji sejauh mana probabilitas terjadinya variabel dependen dapat diprediksi dengan variabel independen. Pada teknik analisis regresi logistik tidak memerlukan lagi uji normalitas dan uji asumsi klasik pada variabel bebasnya (Ghozali, 2011).

Pengujian hipotesis dilakukan secara multivariate dengan mengunakan regresi logistik. Pengertian analisis regresi logistik adalah suatu metode analisis yang berfungsi untuk menganalisa pengaruh suatu variable bebas terhadap suatu variable terikat, dengan syarat bentuk data dari variable terikat adalah data dikotomi, seperti ya dan tidak, setuju dan tidak, wanita dan pria, dan sebagainya (Baroroh, 2013). Regresi logistik digunakan apabila variable dependennya adalah satu nonmetrik dengan dua kategori dan variable independen adalah satu atau lebih metrik dan non-metrik (Ghozali, 2011).

Variabel dependen dalam penelitian ini adalah pergantian KAP yang dinyatakan dengan pengukuran dummy, dimana kategori 1 untuk perusahaan yang melakukan pergantian KAP dan kategori 0 untuk perusahaan yang tidak melakukan pergantian KAP.

Pengujian hipotesis dapat dilihat melalui koefisien regresi. Koefisien regresi dari tiap variabel-variabel yang diuji menunjukkan bentuk hubungan antara variabel. Pengujian hipotesis dilakukan dengan cara membandingkan antara nilai probabilitas (sig) dengan tingkat signifikasi $(\alpha)$. Jika nilai probabilitas (sig) $<$ dari 0,05 (tingkat signifikansi $/ \alpha$ ) maka berarti Ho ditolak dan Ha diterima yang berarti bahwa variabel bebas berpengaruh secara signifikan terhadap terjadinya variabel terikat. Begitu pula sebaliknya, bila nilai probabilitas (sig) > dari 0,05 (tingkat signifikansi / $\alpha$ ) maka berarti Ho diterima dan Ha ditolak yang berarti bahwa variabel bebas tidak berpengaruh secara signifikan terhadap terjadinya variabel terikat. Regresi logistik juga mengabaikan heteroscedacity, artinya variable dependen tidak memerlukan homoscedacity untuk masingmasing variable independennya. Model regresi logistik yang digunakan oleh Ghozali (2006) dalam Sinarwati (2010) menjelaskan:

$\operatorname{Ln} \underline{\mathrm{P}(\mathrm{KAP})}=\alpha+\beta 1 \mathrm{X} 1+\beta 2 \mathrm{X} 2+\varepsilon \ldots$

\section{$1-\mathrm{P}(\mathrm{KAP})$}

Keterangan:

A $\quad=$ Konstan

PKAP $=$ Pergantian KAP

$\beta \mathrm{I} \quad=$ Koefiesien Regresi, dimana

$\mathrm{i}=1,2,3, \mathrm{dst}$

$\varepsilon \quad=$ Error

Sehingga model regresi logistik yang digunakan untuk menguji hipotesis penelitian ini adalah sebagai berikut:

$S W I T C H=\beta 0+\beta 1(\mathrm{OP})+\beta 2(\mathrm{PP})+\varepsilon \ldots$

Di mana:

SWITCH $=$ Pergantian KAP

$\beta 0=$ Koefisien Regresi

$\mathrm{OP}=$ Opini audit

PP = Pertumbuhan perusahaan

$\varepsilon \quad=$ Error

\section{HASIL DAN PEMBAHASAN}

\section{Statistik deskriptif}

Bagian statistik deskriptif bertujuan untuk melihat distribusi data dari variable yang digunakan dalam penelitian ini. Berdasarkan hasil statistik deskriptif, maka dapat diinterpretasikan nilai minimum, nilai maksimum, nilai mean (rata-rata), nilai standar deviasi. Nilai minimum merupakan nilai terendah untuk setiap 
variabel, sedangkan nilai maksimum merupakan nilai tertinggi untuk setiap variabel dalam penelitian. Nilai mean merupakan nilai rata-rata dari setiap variabel yang diteliti. Dan standar deviasi menggambarkan disperse atau variasi dari variabel-variabel tersebut. Hasil dari statistik deskriptif dalam penelitian ini dapat dilihat pada tabel 4.1 berikut ini

Tabel 4.1 Statistik Deskriptif

\begin{tabular}{|l|l|l|l|l|l|}
\hline $\begin{array}{l}\text { Vrb } \\
\mathbf{l}\end{array}$ & $\mathbf{N}$ & $\begin{array}{l}\text { Mi } \\
\mathbf{n}\end{array}$ & $\begin{array}{l}\text { Ma } \\
\mathbf{x}\end{array}$ & $\begin{array}{l}\text { Mea } \\
\mathbf{n}\end{array}$ & $\begin{array}{l}\text { Std } \\
\text { Deviatio } \\
\mathbf{n}\end{array}$ \\
\hline PP & $\begin{array}{l}18 \\
8\end{array}$ & -0.9 & 62.5 & 0.64 & 5.212 \\
\hline
\end{tabular}

Sumber Data Primer

Diketahui bahwa jumlah data yang digunakan dalam penelitian ini sebanyak 47 x $4=188$ sampel data yang diambil dari laporan keuangan dan laporan audit yang tercatat di Bursa Efek Indonesia periode 2013-2017. Nilai minimum, maksimun, mean dan standard deviasi variable dijelaskan dengan hasil perhitungan yang telah dilakukan, nilai minimum PP atau pertumbuhan perusahaan perusahaan adalah sebesar -.9740 dimiliki oleh PT. Sugih Energy, Tbk pada tahun 2014, nilai maksimun sebesar 62.5083 dimiliki oleh PT Sugih Energy, Tbk pada tahun 2015. Mean (rata-rata) pertumbuhan perusahaan manufaktur adalah sebesar 0.641258 dan standard deviasi 5.2121947

Tabel 4.2 Distribusi Sampel KAP

\begin{tabular}{|c|c|c|c|c|}
\hline & $\begin{array}{c}\text { Fre } \\
\mathbf{q}\end{array}$ & $\begin{array}{c}\text { Percen } \\
\mathbf{t}\end{array}$ & $\begin{array}{c}\text { Vali } \\
\mathbf{d} \\
\mathbf{\%}\end{array}$ & $\begin{array}{c}\text { Cumulativ } \\
\mathbf{e} \\
\mathbf{\%}\end{array}$ \\
\hline $\begin{array}{c}\text { Valid } \\
.000 \\
0\end{array}$ & 111 & 59.0 & 59.0 & 59.0 \\
\hline $\begin{array}{c}1.00 \\
0\end{array}$ & 77 & 41.0 & 41.0 & 100.0 \\
\hline
\end{tabular}

Berdasarkan tabel 4.2 dari 188 data observasi diperoleh sebanyak 111 data atau
$59 \%$ dari total observasi tidak melakukan pergantian KAP, dan sebanyak 77 data atau $41 \%$ dari total observasi melakukan pergantian KAP. Perbandingan tersebut menunjukkan bahwa pada umumnya perusahaan manufaktur di Bursa Efek Indonesia (BEI) lebih banyak yang tidak melakukan pergantian KAP daripada yang melakukan pergantian KAP.

Tabel 4.3 Distribusi Sampel OA

\begin{tabular}{|c|c|c|c|c|}
\hline & $\begin{array}{c}\text { Fre } \\
\mathbf{q}\end{array}$ & $\begin{array}{c}\text { Percen } \\
\mathbf{t}\end{array}$ & $\begin{array}{c}\text { Vali } \\
\mathbf{d} \\
\mathbf{\%}\end{array}$ & $\begin{array}{c}\text { Cumulativ } \\
\mathbf{e} \\
\mathbf{\%}\end{array}$ \\
\hline $\begin{array}{c}\text { Valid } \\
.000 \\
0\end{array}$ & 92 & 48.9 & 48.9 & 48.9 \\
\hline $\begin{array}{c}1.00 \\
0\end{array}$ & 96 & 51.1 & 51.1 & 100.0 \\
\hline
\end{tabular}

Sumber Data Primer

Berdasarkan tabel 4.3 dari 188 data observasi diperoleh sebanyak 92 data atau $48,9 \%$ dari total observasi mendapatkan opini audit unqualified, dan sebanyak 96 data atau $51,1 \%$ dari total observasi mendapatkan opini audit selain unqualiefied. Perbandingan tersebut menunjukkan bahwa perusahaan manufaktur di Bursa Efek Indonesia (BEI) lebih banyak mendapatkan opini audit selain unqualified seperti qualified, going concern, adverse atau disclaimer.

\subsection{Hasil Uji Hipotesis Penelitian}

Hipotesis dalam penelitian ini diuji dengan menggunakan model regresi logistik (logistic regression). Tujuannya adalah untuk memperoleh gambaran yang menyeluruh mengenai pengaruh variabel independen (opini audit, dan pertumbuhan perusahaan) terhadap variabel dependen yaitu pergantian Kantor Akuntan Publik (KAP). Tahapan-tahapannya adalah sebagai berikut: 


\subsubsection{Hasil Uji Kelayakan Model Regresi}

Analisis yang dilakukan adalah menilai kelayakan model regresi logistik biner. Menilai kelayakan dari model regresi dapat dilakukan dengan memperhatikan goodness of fit model yang diukur dengan Chi-Square pada kolom Hosmer and Lemeshow's (Ghozali, 2011). Hipotesis yang digunakaan untuk menilai kelayakan model regresi ini adalah:

Ho: Tidak ada perbedaan antara model dengan data

Ha: Ada perbedaan antara model dengan data

Menilai kelayakan dari model regresi ini dapat dilakukan dengan memperhatikan goodness of fit model yang diukur dengan Chi-Square pada kolom Hosmer and Lemeshow's (Ghozali, 2011). Jika nilai Hosmer and Lemeshow Goodness-of-fit-test statistics sama dengan atau kurang dari 0.05, maka hipotesis nol ditolak yang berarti ada perbedaan signifikan antara model dengan nilai observasinya sehingga Goodness fit model tidak dapat memprediksi nilai observasinya. Jika nilai Hosmer and Lemeshow Goodness-of-fit-test statistics lebih besar dari 0.05, maka hipotesis nol tidak dapat ditolak dan berarti model mampu memprediksi nilai observasinya atau dapat dikatakan model dapat diterima karena cocok dengan data observasinya. Hal ini berarti model regresi layak dipakai untuk analisis selanjutnya, karena tidak ada perbedaan yang nyata antara klasifikasi yang diprediksi dengan klasifikasi yang diamati. Hasil uji kelayakan model regresi dapat dilihat pada tabel 4.4 dibawah ini:

Tabel 4.4 Uji Kelayakan Model Regresi Hosmer and Lemeshow Test

\begin{tabular}{|c|c|c|c|}
\hline Step & $\begin{array}{c}\text { Chi- } \\
\text { square }\end{array}$ & Df & Sig \\
\hline 1 & 7.868 & 8 & .446 \\
\hline
\end{tabular}

Tabel 4.4 menunjukan hasil pengujian Hosmer and Lemeshow's Test. Berdasarkan tabel tersebut, dapat diketahui bahwa nilai signifikansi adalah sebesar 0,446. Nilai signifikan yang diperoleh tersebut diatas 0,05 yang berarti hipotesis 0 (Ho) tidak dapat ditolak (diterima). Hal ini berarti model mampu memprediksi nilai observasinya atau model dapat diterima karena cocok dengan data observasinya sehingga model ini dapat digunakan untuk analisis selanjutnya.

\subsubsection{Menilai Keseluruhan Model Regresi (Overall Fit Model)}

Pengujian kesesuaian keseluruhan model (Overall Fit Model) dilakukan dengan membandingkan nilai antara $-2 \log$ Likelihood (-2LL) pada awal (Block Number $=0)$ dengan nilai -2 Log Likelihood (-2LL) pada akhir (Block Number $=1$ ). Hipotesis untuk menilai model fit:

Ho = Model yang dihipotesiskan fit dengan data

$\mathrm{Ha}=$ Model yang dihipotesiskan tidak fit dengan data

Berdasarkan hipotesis ini, maka Ho harus dterima dan $\mathrm{Ha}$ harus ditolak agar model fit dengan data. Statistik yang digunakan berdasarkan fungsi likelihood. Likelihood L dari model adalah probabilitas bahwa model yang dihipotesiskan menggambarkan data input.

Tabel 4.5 adalah Iteration History 0 yang merupakan -2Log Likelihood awal. Tabel ini akan dibandingkan dengan tabel 4.9, tabel Iteration History 1 yang merupakan -2Log Likelihood akhir. Adanya selisih antara -2 Log Likelihood awal dengan -2 Log Likelihood akhir menunjukan bahwa hipotesis nol (H0) tidak dapat di tolak dan model fit dengan data.

Tabel 4.5 Menilai Keseluruhan Model Iteration History ${ }^{\mathrm{a}, \mathrm{b}, \mathrm{c}}$

\begin{tabular}{|c|c|c|}
\hline Iteration & $\begin{array}{c}-2 \text { Log } \\
\text { Likelihood }\end{array}$ & Coefficient \\
\cline { 3 - 3 } & & Constant \\
\hline
\end{tabular}




\begin{tabular}{|c|l|l|}
\hline Step 1 & 254.441 & -3.62 \\
\hline 2 & 254.440 & -3.66 \\
\hline 3 & 254.44 & -3.66 \\
\hline
\end{tabular}

Sumber: data primer

Berdasarkan hasil pengolahan SPSS ver. 21 pada tabel 4.5 menunjukan bahwa nilai -2 Log Likelihood awal (tabel Iteration History 0) adalah sebesar 254,440. Secara matematis, angka tersebut signifikan pada alpha 5\% dan berarti bahwa hipotesis nol (H0) ditolak. Hal ini berarti hanya konstanta saja yang tidak fit dengan data (sebelum dimasukkan variabel bebas ke dalam model regresi) (Ghozali, 2011).

Langkah selanjutnya adalah membandingkan antara nilai $-2 \quad \log$ Likelihood awal ( tabel Iteration History 0) dengan -2 Log Likelihood akhir (tabel Iteration History 1), Pada tabel Iteration History 0, nilai -2 Log Likelihood awal menunjukan sebesar 254,440. Setelah variabel bebas dimasukan pada model regresi, maka nilai -2 Log Likelihood pada tabel 4.13 Iteration History 1 adalah sebesar 249.305 .

Tabel 4.6 Iretation History 1 Iretation History $^{\text {a,b,c,d }}$

\begin{tabular}{|c|l|l|l|l|}
\hline Iteration & $\begin{array}{l}-2 \\
\text { Likel }\end{array}$ & \multicolumn{3}{|c|}{ Coefficients } \\
\cline { 3 - 5 } & ihood & Con & X1 & X2 \\
& & stant & & \\
\hline Step 1 & 249.635 & -0.40 & - & - \\
& & & .525 & .025 \\
\hline 2 & 249.363 & -0.35 & - & - \\
& & & .543 & .044 \\
\hline 3 & 249.309 & -0.34 & - & - \\
& & & .541 & .058 \\
\hline 4 & 249.305 & -0.34 & - & - \\
& & & .541 & .063 \\
\hline
\end{tabular}

\begin{tabular}{|l|l|l|l|l|}
\hline 5 & 249.305 & -0.34 & - & - \\
& & & .541 & .064 \\
\hline
\end{tabular}

Berdasarkan output tersebut, terjadi penurunan nilai antara-2 Log Likelihood awal dan akhir sebesar 5.135. Penurunan nilai-2 Log Likelihood ini dapat diartikan bahwa penambahan variabel bebas ke dalam model dapat memperbaiki model fit serta menunjukan model regresi yang lebih baik atau dengan kata lain model yang dihipotesiskan fit dengan data.

\subsubsection{Hasil Uji Koefisien Determinasi (Nagelkerke R Square)}

Koefisien determinasi dalam regresi logistik biner (binary logistic) ditunjukan dengan nilai Nagelkerke $R$ Square. Nagelkerke $R$ Square dapat diiterpretasikan seperti nilai $R$ Square dalam regresi berganda yang digunakan untuk menjelaskan seberapa besar variabilitas variable independennya (Ghozali, 2011). Hasil uji tersebut dapat dilihat pada tabel 4.7 dibawah ini:

\section{Tabel 4.7 Koefisien Determinasi Model Summary}

\begin{tabular}{|c|c|c|c|}
\hline $\begin{array}{c}\text { Ste } \\
\mathbf{p}\end{array}$ & $\begin{array}{c}\mathbf{- 2} \text { Log } \\
\text { likeliho } \\
\text { od }\end{array}$ & $\begin{array}{c}\text { Cox\&Sn } \\
\text { ell R } \\
\text { Square }\end{array}$ & $\begin{array}{c}\text { Nagerker } \\
\text { ke R } \\
\text { Square }\end{array}$ \\
\hline 1 & $249.305^{\mathrm{a}}$ & .027 & .036 \\
\hline
\end{tabular}

Besarnya nilai koefisien determinasi pada model regresi logistik ditunjukkan oleh nilai Nagelkerke $R$ Square. Nilai Nagelkerke RSquare adalah sebesar 0,036 yang berarti variabilitas variabel dependen yang dapat dijelaskan oleh variabel independen adalah sebesar $3,6 \%$, sedangkan sisanya sebesar $95,4 \%$ dijelaskan oleh variabel-variabel lain di luar model penelitian, seperti fee audit, reputasi klien, reputasi KAP, perubahan kontrak, kepemilikan saham klien, pergantian manajemen klien dan lain-lain. 


\subsubsection{Hasil Matriks Klasifikasi}

Matriks klasifikasi menunjukkan kekuatan prediksi dari model regresi untuk memprediksi kemungkinan pergantian KAP yang dilakukan oleh perusahaan (Ghozali, 2011). Hasil tersebut dapat dilihat pada tabel 4.8 di bawah ini

\section{Tabel 4.8 Matriks Klasifikasi Classification Tabel}

\begin{tabular}{|l|c|c|c|}
\hline \multirow{2}{*}{ Observed } & \multicolumn{3}{|c|}{ Predicted } \\
\cline { 2 - 3 } & \multicolumn{2}{|c|}{ Switch } & $\begin{array}{c}\text { Percentag } \\
\text { e }\end{array}$ \\
\cline { 2 - 3 } & $\begin{array}{c}\mathbf{. 0 0 0} \\
\mathbf{0}\end{array}$ & $\begin{array}{c}\mathbf{1 . 0 0} \\
\mathbf{0}\end{array}$ & Correct \\
\hline $\begin{array}{l}\text { Step 1 } \\
\text { Switch.000 } \\
0\end{array}$ & 110 & 1 & 99.1 \\
\hline 1.000 & 73 & 4 & 5.2 \\
\hline Overall & & & 60.6 \\
\hline
\end{tabular}

Kekuatan prediksi dari model regresi untuk memprediksi kemungkinan perusahaan melakukan pergantian KAP adalah sebesar 5,2\%. Hal ini menunjukkan bahwa dengan menggunakan model regresi yang digunakan, terdapat sebanyak 4 perusahaan $(5,2 \%)$ yang melakukan pergantian KAP dari total 77 perusahaan yang melakukan pergantian KAP. Kekuatan prediksi model perusahaan yang tidak melakukan pergantian KAP adalah sebesar $99,1 \%$, yang berarti bahwa dengan model regresi yang digunakan ada sebanyak 110 perusahaan $(99,1 \%)$ yang tidak melakukan pergantian KAP dari total 111 perusahaan yang melakukan pergantian KAP. Kekuatan model prediksi keseluruhan sebesar $60,6 \%$.

\subsubsection{Uji Multikolinieritas}

Model regresi yang baik adalah regresi dengan tidak adanya gejala korelasi yang kuat di antara variabel bebasnya. Pengujian ini menggunakan matrik korelasi antar variabel bebas untuk melihat besarnya korelasi antar variabel independen. Apabila nilai koefisien korelasi antar variabel bebas lebih kecil dari 0,9 berarti tidak terdapat gejala multikolinearitas yang serius antar variabel bebas tersebut (Ghozali, 2011). Uji tersebut dapat dilihat pada tabel 4.9 dibawah ini:

Tabel 4.9 Matriks Korelasi antar VB Correlation Matriks

\begin{tabular}{|c|c|c|c|}
\hline & Constant & OA & PP \\
\hline $\begin{array}{c}\text { Step 1 } \\
\text { Cons }\end{array}$ & 1.000 & -.675 & -.031 \\
\hline OA & -.675 & 1.000 & -.065 \\
\hline PP & -.031 & -.065 & 1.000 \\
\hline
\end{tabular}

Menurut Ghozali (2011), jika antar variabel independen ada korelasi yang cukup tinggi diatas 0,90 maka hal ini merupakan indikasi adanya multikolinaritas. Hasil pengujian menunjukkan tidak ada nilai koefisien korelasi antar variable independen yang nilainya lebih besar dari 0,90 maka dapat disimpulkan tidak terdapat indikasi multikolinearitas antar variabel independen.

\subsubsection{Hasil Uji Regresi Logistik}

Tabel 4.10 Hasil Uji Koefisien Regresi Logistik Variables in the Equation

\begin{tabular}{|l|l|l|l|l|l|l|l|l|}
\hline & & & & & & & \multicolumn{2}{|l}{$\begin{array}{l}\text { 95\% C.I for } \\
\text { EXP (B) }\end{array}$} \\
& & B & S.E. & ald & Df & Sig. & Xp & \multicolumn{2}{|l|}{ (B) } & $\begin{array}{l}\text { Lo } \\
\text { wer }\end{array}$ & $\begin{array}{l}\text { Upp } \\
\text { er }\end{array}$ \\
\hline 1 & -.541 & .303 & .189 & 1 & .074 & .582 & .322 & $\begin{array}{l}1.05 \\
4\end{array}$ \\
\hline X2 & -.064 & .094 & 464 & 1 & .496 & .938 & .781 & $\begin{array}{l}1.12 \\
8\end{array}$ \\
\hline ons & -.034 & .226 & 022 & 1 & .882 & .967 & & \\
\hline
\end{tabular}

\section{Sumber : Data Primer}

Hasil pengujian terhadap koefisien regresi menghasilkan model berikut:

SWITCH $=-0,034-0,5410 A-0,064 P P$ 
Pengujian hipotesis dilakukan dengan cara membandingkan antara tingkat signifikansi (sig) dengan tingkat kesalahan $(\alpha)=5 \%$.

Berdasarkan tabel 4.10 yang ada dapat di interpretasikan sebagai berikut:

\section{1) Pengujian hipotesis pertama $\left(\mathrm{H}_{1}\right)$}

Hipotesis pertama menyatakan bahwa variable opini audit berpengaruh positif terhadap pergantian Kantor Akuntan Publik (KAP). Hasil pengujian menunjukkan variable opini audit yang diproksikan dengan variable dummy memiliki koefisien regresi negatif sebesar -0,541 dengan tingkat signifikansi $0,074>\alpha \quad 0,05$. Berdasarkan hal tersebut dapat disimpulkan bahwa variable opini audit tidak berpengaruh signifikan terhadap pergantian $\mathrm{KAP}$ atau dengan kata lain $\mathrm{H}_{1}$ diterima

\section{2) Pengujian hipotesis kedua $\left(\mathbf{H}_{2}\right)$}

Hipotesis kedua menyatakan bahwa variable pertumbuhan perusahaan berpengaruh positif terhadap pergantian Kantor Akuntan Publik (KAP). Hasil pengujian menunjukkan variable pertumbuhan perusahaan yang diproksikan dengan pertumbuhan penjualan bersih perusahaan memiliki koefisien regresi negatif sebesar $-0,064$ dengan tingkat signifikansi 0,496 $>\alpha 0,05$. Berdasarkan hal tersebut dapat disimpulkan bahwa variable pertumbuhan perusahaan tidak berpengaruh signifikan terhadap pergantian KAP atau dengan kata lain $\mathrm{H}_{2}$ diterima.

\section{c. Pembahasan Hasil Penelitian}

Pada bagian pembahasan ini akan dijelaskan mengenai pengaruh setiap variable independen yang meliputi opini audit, dan pertumbuhan perusahaan terhadap pergantian Kantor Akuntan Publik (KAP) sebagai variable dependen dimana penelitian ini merupakan studi empiris pada perusahaan manufaktur yang terdaftar di Bursa Efek Indonesia (BEI). Hasil pengujian dan pembahasannya antara lain:

\subsubsection{Opini Audit dengan Pergantian $\operatorname{KAP}\left(\mathbf{H}_{1}\right)$}

Hasil penelitian menunjukkan bahwa variable opini audit memiliki koefisien regresi negatif sebesar $-0,541$ dengan tingkat signifikansi 0,074 lebih besar daripada $\alpha 0,05$. Berdasarkan hal tersebut dapat disimpulkan bahwa variable opini audit yang diukur dengan pengukuran dummy tidak berpengaruh signifikan terhadap pergantian Kantor Akuntan Publik (KAP). Penelitian ini membuktikan bahwa teori agensi yang mengungkapkan bahwa kemungkinan klien akan mengganti KAP jika mendapat opini audit yang tidak sesuai harapan manajer tidak terbukti. Hasil pekerjaan auditor dan proses audit yang dilaksanakan oleh KAP menunjukkan bahwa kualitas opini yang dihasilkan sesuai dengan standar yang berlaku. Walaupun perusahaan tidak mendapat opini audit yang terbaik yaitu wajar tanpa pengecualian dari KAP yang mengauditnya, menunjukkan jelas kualitas laporan keuangan perusahaan sesuai dengan standar yang berlaku sehingga memberikan anggapan positif kepada para pengguna laporan keuangan.

Hasil penelitian ini sejalan dengan Damayanti dan Sudarma (2008), Chadegani et al (2011), serta Wijayani dan Januarti (2011) yang mengungkapkan bahwa opini audit tidak berpengaruh terhadap pergantian KAP. Namun hasil penelitian ini tidak didukung dengan penelitian yang dilakukan oleh Chow and Rice (1982) dan Lennox (2000) tidak didukungnya hipotesis yang diuji karena ketika perusahaan diaudit oleh KAP big four akan berpindah ke KAP non big four dikhawatirkan akan menyebabkan anggapan negative dari para pengguna laporan keuangan terhadap kualitas laporan keuangan perusahaan. Sebaliknya jika perusahaan berpindah dari KAP non big four ke KAP big four, dikhawatirkan dapat menyebabkan kemungkinan perusahaan tidak mendapat opini wajar tanpa pengecualian karena kualitas audit yang lebih baik. 
Banyaknya perusahaan yang mendapatkan opini selain unqualified seperti going concern pada perusahaan yang dijadikan sampel pada penelitian ini dikarenakan beberapa induk perusahaan dan anak perusahaan di audit oleh kantor akuntan publik yang berbeda sehingga auditor harus mengungkapkannya dalam laporan audit independen. Tujuan audit atas laporan keuangan oleh auditor independen pada umumnya adalah untuk menyatakan pendapat tentang kewajaran, dalam semua hal yang material, posisi keuangan, hasil usaha perubahan ekuitas, dan arus kas sesuai standar akuntansi keuangan di Indonesia. Laporan auditor merupakan sarana bagi auditor untuk menyatakan pendapatnya, atau apabila keadaan mengharuskan, untuk menyatakan tidak memberikan pendapat, ia harus menyatakan apakah auditnya telah dilaksanakan berdasarkan standar auditing yang ditetapkan Institut Akuntan Publik Indonesia (IAPI, 2013).

\subsubsection{Pertumbuhan Perusahaan dengan Pergantian KAP $\left(\mathrm{H}_{2}\right)$}

Hasil penelitian menunjukkan bahwa variable pertumbuhan perusahaan memiliki koefisien regresi negatif sebesar 0,064 dengan tingkat signifikansi 0,496 lebih besar daripada $\alpha 0,05$. Berdasarkan hal tersebut dapat disimpulkan bahwa variable pertumbuhan perusahaan yang diukur dengan pertumbuhan penjualan bersih tidak berpengaruh signifikan terhadap pergantian Kantor Akuntan Publik (KAP). Penelitian ini membuktikan bahwa pertumbuhan perusahaan memberikan sorotan kepada para pengguna laporan keuangan dimana pertumbuhan tersebut sangat berkaitan erat terhadap corporate action. Dengan meningkatnya pertumbuhan perusahaan, corporate action seperti penerbitan saham baru (right issues), penawaran tender (tender offer) termasuk di pengeluaran obligasi akan mengalami peningkatan juga. Aksi korporasi ini akan berdampak bagi peningkatan kinerja perusahaan. Hal tersebut memberikan perhatian lebih khususnya oleh pengguna laporan keuangan, sehingga mengurangi keinginan atau dorongan untuk mengganti KAP.

Hasil penelitian ini sejalan dengan penelitian Nasser et al (2006) namun tidak didukung oleh penelitian yang dilakukan oleh Prastiwi dan Wilsya (2009). Hal ini menunjukkan bahwa walaupun perusahaan mengalamai pertumbuhan pada penjualannya, tidak mampu mendorong perusahaan untuk mengganti KAP yang mengaduitnya. Perusahaan yang sedang mengalami pertumbuhan, lebih sering mendapat perhatian dari publik dan pengguna laporan keuangan, sehingga tidak semudah itu mengambil keputusan untuk mengganti KAP yang mengauditnya karena akan mendapat atensi dari publik. Hal tersebut wajar karena perusahaan ingin memiliki reputasi yang baik di mata publik dan pengguna laporan keuangan. Jadi tidak hanya melihat penjualan saja yang meningkat mampu membuat keputusan mengganti KAP. Banyak faktor pertumbuhan selain penjualan yang mampu untuk mempertimbangkan reputasi perusahaan di lingkungan bisnis.

Penelitian ini tidak didukung oleh penelitian lainnya karena banyak faktor variable diluar penjualan yang dijadikan proksi untuk menghitung tingkat pertumbuhan perusahaan yang mampu menjelaskan tentang fenomena pergantian KAP.

\section{KESIMPULAN}

Dari pengujian yang telah dilakukan terhadap permasalahan yang dirumuskan dalam hipotesis penelitian dengan menggunakan regresi logistik (logistic regression), berdasarkan hasil analisis dan pembahasan maka dapat diambil kesimpulan:

1. Opini audit tidak berpengaruh terhadap pergantian Kantor Akuntan Publik (KAP) dengan kesimpulan $\mathrm{H}_{1}$ diterima. Opini audit yang diberikan auditor seharusnya berdasarkan kepatuhan terhadap standar auditing, kode etik akuntan publik dan 
sistem pengendalian mutu. Untuk mendukung opini auditnya, auditor harus mengumpulkan bahan bukti audit yang cukup kompeten. Sehingga opini pada perusahaan manufaktur yang terdaftar di BEI telah dikeluarkan berdasarkan kepatuhan tersebut.

2. Pertumbuhan perusahaan tidak berpengaruh terhadap pergantian Kantor Akuntan Publik (KAP) dengan kesimpulan $\mathrm{H}_{3}$ diterima. Pertumbuhan perusahaan umumnya akan mendapat atensi lebih dari lingkungan bisnisnya karena berhubungan dengan corporate action yang dilakukan oleh perusahaan, sehingga menjaga agar reputasi yang tidak baik ketika harus mengambil keputusan mengganti KAP yang mengaduitnya dapat dihindari

\section{DAFTAR PUSTAKA}

Agoes, S., \& Hoesada, J. . (2012). Bunga Rampai Auditing (Edisi 2 ed.). Jakarta: Salemba Empat.

Atkinson, A., \& Feltham, G. (1982). Research to Support Standart Setting in Financial Accounting : A Canadian Perspective. Agency Theory Research and Financial Accounting Standards, 260.

Baroroh, A. (2013). Analisis Multivariat dan Time Series dengan SPSS 21. Jakarta: PT. Elex Media Komputindo.

Chadegani, A. A., Mohamed, Z. M., \& Jari, A. (2011). The Determinant Factors of Auditor Switch among Companies Listed on Tehran Stock Exchange. International Conference on Sociality and Economic Development, 10.

Chow, C. W., \& Rice, S. J. (1982). Qualified Audit Opinion and Auditor Switching. The Accounting Review. The Accounting Review $\operatorname{LVII}(2), 326-225$.

Damayanti, S., \& Sudarma, M. (2008). Faktor-Faktor yang Mempengaruhi Perusahaan Berpindah Kantor Akuntan Publik. Simposium Nasional Akuntansi XI.
Ghozali, I. (2011). Aplikasi Analisis Multivariate dengan program IBM SPSS (Edisi 5 ed.). Semarang: Badan Penerbit Universitas Diponegoro.

Giri, E. F. (2010). Pengaruh Tenur Kantor Akuntan Publik (KAP) dan Reputasi KAP Terhadap Kualitas Audit: Kasus Rotasi Wajib Auditor di Indonesia. Simposium Nasional Akuntansi XIII Purwokerto 2010., 26.

Lennox, C. (2000). Do Companies Succesfully Engange in OpinionShopping?Evidence from the UK. Journal of Accounting \& Economics, 321-337.

Nasser, A.A. T., Wahid, E. A., Syed Mustapha Nazri, S. N., \& Hudaib, M. (2006). Auditor-Client Relationship: The Case of Audit Tenure and Auditor Switching in Malaysia. Managerial Auditing Journal, 724-737.

Praptitorini, M. D., \& Januarti, I. . (2007). Analisis Pengaruh Kualitas Audit, Debt Default, dan Opinion Shopping terhadap Penerimaan Opini Going Concern. Simposium Nasional Akuntansi X Makasar.

Prastiwi, A., \& Wilsya, F. . (2009). FaktorFaktor yang Mempengaruhi Pergantian Auditor: Studi Empiris Perusahaan Publik di Indonesia. Jurnal Dinamika Akuntansi.

Sekaran, U. (2006). Research Methods for Bussiness. 3rd Edition. New York: John Wiley and Sons Inc.

Sinarwati, N. K. (2010). Mengapa Perusahaan Manufaktur yang Terdaftar di BEI Melakukan Pergantian Kantor Akuntan Publik? Simposium Nasional Akuntansi XIII Purwokerto, 20.

Sumarwoto. (2006). Pengaruh Kebijakan Rotasi KAP terhadap Kualitas Laporan Keuangan. Program Pasca Sarjana Universitas Diponegoro.

Wijayani, E. D., \& Januarti, I. (2011). Analisis Faktor-Faktor yang 
Mempengaruhi Perusahaan di

Indonesia melakukan Auditor

Switching. Simposium Nasional

Akuntansi XIV Aceh, 25. 